\title{
ALBANIAN LANGUAGE AND THE USE OF FOREIGN WORDS IN SCHOOL AGE
}

\author{
Dr. Helena Grillo Mukli \\ University "Aleksander Moisiu” Durres \\ Department of Albanian Language \\ e-mail helenagrillo@yahoo.com
}

\section{Introduction}

"The Albanian language has a particular importance in the pre-university education curricula. This subject enables the students to gain knowledge and demonstrate skills, values and behaviors on the linguistic system of Albanian language; values and beliefs to properly communicate (speaking, listening, reading and writing." The curricula in Albania has changed dramatically. The actual curricula for grades 1-9 are a product of basic education reform, performed during 2003-2008, which enabled the change of education structure from eight to nine years and some other positive changes of the respective curricula. ${ }^{1}$

As an important part of the linguistic formation of the children in school age, mainly 14-15 years, the studies for the Albanian language, teaching methodology and learning competencies as a first language, or even as a second language for the national minorities vary a lot. These studies not only observe and analyze the linguistic formation of the children, but more often come to recommendations and valuable strategies to improve and gain the basic competencies of Albanian language in both its varieties and different speech registers. This study aims to perform measurements of the linguistic formation of the school age students in the area of lexicon, usage of foreign words, which is a phenomenon that is very common in school age and faces Albanian language with the globalization challenges confronting other languages. This is an aspect without stopping in school texts and foreign terminology issues. This methodological approach used in this study for children who are native speakers of Albanian language, will ne used on children who learn the Albanian language as a second language. This will serve to investigate the tendency of using foreign words in Albanian language.

According to Cabej "there is a variety of native words, that without meaning damage, are able to replace foreign words" adding that "it is interesting that the native words are better understood, are better spoken from the students of young ages, as these words form associations of ideas; they find their analogy in the lexical assets that the students possess within the native language system"

The use of foreign words while they have their synonyms in Albanian is becoming very common nowadays. Because of this, in order to assess how do the students use and understand these words, we performed a questionnaire which has some measurements. The questionnaire includes four parts in various measurement levels, which aim to discover how the foreign words are used, their meaning, and what is the tendency to replace their Albanian synonyms, or which is the competitive form which is mostly used from the group age that participated in the study. This questionnaire is completed from the students of 14-15 years old, respectively grade eight and nine. The study was performed in the School of "Vore" and "Ismail Qemali" school in the city of Vlore. The questionnaire is found at the end of the study.

The questionnaire is completed from 100 students, without taking into consideration their geographical and dialect variants, as the measurements are performed using the official written language. Within the questionnaire we included common foreign words used in Albanian language. The main goal was to test the students if they recognized these

${ }^{1}$ Curricula of Albanian language, MAS, Tirana, 2015 
words, write them properly and to know their meaning or replace them with the Albanian equivalents, and finally to use them in the grammar system, mainly in proper meaning with the other words.

\title{
Measurement I
}

On the text below we investigate the recognition of labeling as foreign language words for the underlined words and the ability of the students to find their equivalent Albanian word.

Qëllimi i këtij prezantimi është të konstatojmë në vlerat e këtij autori të njohur ndërkombëtarisht. Personalisht, ai ka qenë gjithmonë kundër dhe nuk ka insistuar në promovimin e veprave letrare të botuara. Por, është obligimi i të gjithë mediave, shkollave dhe individëve që e çmojnë letërsinë e mirë të flasin për teknikat e ndërtimit të veprës dhe mesazhet universale që mbart.

PS: note of the author- the test is left in Albanian in order to show the difference between the Albanian and underlined foreign words.

We notice that the level of meaning recognition of the Albanian equivalent is relatively low. Around $72 \%$ of the students cannot replace the foreign word with the Albanian one. The results show that the students can recognize the foreign words by labeling it, but without replacing it. Around $32 \%$ of the students underlined as foreign words the following words: teknika (technique), personalisht (personally), mediat (media), ndërkombëtarisht (internationally), universal (universal).

The higher number of understanding and Albanian replacement was done for the words insistoj (insist) and konstatoj (find).

Nit understanding of the meaning and origin of the words are reflected in the low language formation of the children. The skill knowledge to replace foreign words with the Albanian equivalent goes through two necessary processes:

a. Recognizing the origin of the word, which goes at the same line as good knowledge in Albanian lexicon, by learning the passive and active words, and the foreign words by origin and meaning.

b. Good knowledge on the grammar system where students gain the necessary skill to use them in sentences.

Learning process on recognition and origin of foreign words is a process that starts early in life, the student should be able to recognize these words and to replace them properly. In order for this to happen, we recommend that the topics of using the foreign words and their recognition to be reviewed, and the students to gain skills and competencies through independent work.

Another approach that we have mentioned is the difference between the school texts offered from the various publishing companies, but this is a very wide issue. Another work to be done is to work with the study books and various terminology and explanation dictionaries from language teachers or individually from the student to improve the use of foreign language.

\author{
Measurement II \\ Circle the proper use: \\ Proçes - process (process)

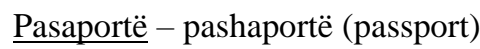 \\ Garazh - garazhd (garage) \\ Eleminim - eliminim (elimination) \\ Dixhital - digjital (digital) \\ Difekt - defect (defect) \\ gen - Gjen (gen) \\ Liçensë - license (license)
}


_buljer - boiler Boljer (water tank)

Dakord- dakort (agree)

This part of the study aims to investigate the writing skills, by later treating the issues found on the way the student writes the foreign words and the if they have the competency to properly write the words.

Pronunciation is a group of rules for the proper pronunciation of the words in a standard language. It is necessary to mention that in studying this competency keeping in mind the use of impact of the variety of the spoken language over the written one we determine that:

a. Pronunciation norm aims to code the spoken language as a model of pronunciation over the dialect, common for all the Albanian language speakers. ${ }^{2}$

b. Pronunciation norm ${ }^{3}$ comes as a generalization and association on one hand of the real necessary realization in more general ones and sound realization that constitutes the phonetic norm as a form of exitance and on the other hand the phonologic system as an association of real realizations.

Based on "Proper writing of Albanian language" consonants in groups ce/ $\mathrm{ci}$ / ge/ gi in foreign words coming from Greek, Latin and Roman languages that have a $c$ followed by $e$ or $i$, are written with $c$, we have selected these words from this group.

Celebrim (celebration), censure (censure), central (central), certificate (certificate), koncesion (concession), leucemi (Leukemia), procedure (procedure), process (process), agjensi (agency), cisternë (Tank), deficit (deficit), license (license), elektricist (electrician), incizoj (tape), klasicizëm (classicism), konciz (concise), recension (recension), Sicilian (Sicilian), suficit (surplus) etc. ${ }^{4}$

And words that come from Greek, Latin and Roman languages that have a $g$ followed by an $e$ or $i$, are written with $g j$ : Gjen (gen), gjenocid (genocide), gjenital (genital), gjips (gyps), gjibon (gibbon), gjirafë (giraffe), agjensi (agency), agjent (agent), algjebër (algebra), angjinë (Angine), digjital (digital) etc. ${ }^{5}$

The linguist Rami Memushaj emphasizes that the users of Albanian language often use the wrong form in foreign words which he labels "linguistic ugliness". He notices these forms: Garazhd instead of garazh (garage), consolidation created from joining the foreign word garazh with the ending sound of the word grazhd: Buljer or boljer instead of bojler

Bulerë or bulir is a water keg, while the word bojler comes from English word boiler "'water heater".

We also underline the words: pasaportë (passport), dakord (agree), defect (defect), eleminim (elimination) which are borrowed ages ago from the Italian and English language and are wrongly used in speaking and written forms from Albanian speakers.

There are three aspects of the literary norm of writing:

1. The first aspect relates to the determination of the phonematic constitution of the words, which is normative; this aspect starts to be appropriated since the beginning of language writing, when children realize the phonematic aspects of the word, continues with the hours of writing in the program of native language and the students exercise written works and exercises. Here the teachers carefully show the students to properly write the words following the rules of proper writing.

2. The second aspect relates to the realization of the allomorphs of the phonemes in various positions of the word, which starts to be learned when the child learns the different paradigms, and the children get the knowledge of the grammar system.

\footnotetext{
${ }^{2}$ Rami Memushaj, Phonetics of Albanian language, “Toena' Publishing, Tirana 2011, pg. 185

${ }^{3}$ B.Beci, Phonologic System of the today literature language and phonetic norms, pg. 93-94

${ }^{4}$ Proper writing of Albanian Language, Tirana 1973, pg. 94.

${ }^{5}$ Proper writing of Albanian Language, Tirana 1973, pg. 96

${ }^{6}$ Rami Memushaj, Standard Albanian, "Toena” Publishing, Tirana, 2008, pg. 112
} 
3. The third aspect relates to the place of accent in the word and in the phonetic units bigger than the word, and the phrase intonation ${ }^{7}$ it associates, the variety of the spoken language, dialect impact or acquired skills even long before the children encounter the learning of the Albanian language in its official function before the language institutionalization. Through this aspect is done the connection with the phonetic principle which is the basics of gaining the linguistic formation. "The main principle of proper writing in Albanian is the phonetic principle: in general words and their meaningful parts are written as they are pronounced in the literary speech. The point of the phonetic principle in Albanian language writing, which is based on a graphic system directly relating to the letter and the sound -phoneme, is the phonologic aspect, which is the social use of language sounds in the process of human relations. The phonetic principle aims to set a close relation between the written and spoken form of the literary language. That is why when in the literary pronunciation are found allowed variations from the today norms, the writing is based on the more generalized form and is in line with the tendency of phonetic system development of the literary Albanian language."

Relating to the pronunciation of a foreign words, the speaker tries to pronounce them starting from the grammar and syntax rules of the Albanian language, gained since early childhood. These words are deformed in such a way that they do not comply to the phonetic rules of Albanian language. As a result, we see changes in the body of the word or in its ending. This relates to the phonemes that precede or follow each other.

The analysis of the measurements about $90 \%$ made mistakes for the words proces, garazh, digjital, gjen, boiler, defekt. The correct use was for the words: eleminim pasaportë. Students were not sure about the word digjital-dixhital. This variation of this word is not memorized well as the result of the language impact of the media or inconsistencies wit the phonetic principle. Meanwhile, there is almost a better pronunciation of the word gen- gjen. This comes as a result of the use of this word from the scientific area such as biology. The word boljer is almost close to the norm as it is close to the spoken language. There is a change noted on the words proces and licensë. The word proces is ahead, as it is marked from many students, especially females, while the word licensë is far from the norm because it is not used very often in the everyday speech.

Results of the second measurement

What we see is that the students do not know the rules of the proper writing of Albanian language. A large number of the students cannot use the correct form. An important factor is the fact that the Albanian language still does not have a code of proper pronunciation and this creates a slow process in learning to use words as they should be used, and the migration process has also had an impact on the joined forms with the standard ones.

\section{Measurement III}

This exercise asked the students to replace foreign words with their equivalent Albanian words. The students were tested in relation to their knowledge about the meaning of the foreign word. In this way we understand the students' skills to explain these words in Albanian. The difficulties in finding the equivalent Albanian word were in high numbers. The bigger mistakes were for the words aplikoj (apply), promovoj (promote), live (live), prioritet (priority). For example, for the word (apply) aplikoj the students replaced it with the words: kërkoj (ask), klikoj (click); the word (promote) promovoj is replaced with the foreign words like inaguroj (inaugurate) and reklamoj (advertise) or with the word trade which is closely related to the media jargon. The word live used a lot in the media is replaced with the words tani (now) and direct (direct). The replacement word direkt is the most used. The word deciziv (decisive) had a lot of explanations. We should also emphasize that some of the students were not able to find the replacement words.

\footnotetext{
${ }^{7}$ Rami Memushaj, Phonetics of Standard Albanian, “Toena” Publishing, Tirana 2011, pg. 186

${ }^{8}$ Proper writing of Albanian Language, Tirana 1973, pg. 1-2
} 
Among the words replaced are: prioritet is replaced with këmbëngul (insist), detyrim (obligation) and aftësi (skill) from two students. The word experience is understood as përjetim (experience), kujtim (memory), and something new. The word deciziv is replaced as $i$ rëndësishëm (important) and $i$ vendosur (determined). The word aplikoj (apply) with the word klikoj (click), the word promovoj (promote) is understood as: reklamoj (advertise), prezantoj (present), publikoj (publish) fillestar (initial), tregoj (show), nxjerr (get out), shfaq (display). The word eksperiencë according to them is qualified as: aftësi (skill), aventurë (adventure), zotësi (capacity), provoj (try), punësoj (employ) and veprimtari e ushtruar (exercised activity). For the word deciziv are given the variations such as: vendim (verdict) vendimarrje (decision), i prerë (strict) and përfundimtar (final).

\section{Results of the third measurement}

The results presented with the examples above show that the students do not know the foreign words and they use them very often. We may even say that they use these words without knowing their meaning, but they simply remember the way they used to during childhood either from sentences or word groups. The biggest issues are found in words that derive from English language such as eksperiencë, live, promovoj etc. As for the Italian derived words it was difficult for the students to find the Albanian equivalent.

Another important issue is the replacement of the written words that do not have any relation with each other. These words such as: rregulloj (fix), mbështes (support), shkarkoj (download) for the word këmbëngul (insist); pyes (ask), interesohem (care), marr pjesë (participate) for the word aplikoj (apply); prekje (touch), ndihmë (help) for the word impact (impact); aftësi (skill), provoj (try), veprimtari (activity) for the word eksperiencë (experience); veçanti (feature) and vullnet (willpower) for the word priority etc. All these students' issues should be fixed by working more with the book of Albanian language and the students themselves should eliminate these words from everyday use.

\section{Measurement IV}

This part aims to investigate the linguistic formation of the students in combining the lexicon aspect and the grammar aspect. Very often the semantic relations are close to the syntax. Syntax plays an important role in the organization of linguistic expressions; it selects from the lexicon a number of words by putting them in a straight line based on rules of joining and movement. The process does not end here, but it continues in sound conversion (phonetic form) and later in meaning realization (logic form).

In this part the goal is that the students apart from the meaning level to put the word into the proper paradigm. According to Comsky ${ }^{9}$ the sentences of human language are not simply a continuance of words, as in many cases the form of words is determined from the form of "distant" words. In general it is thought that the sentences of human language are built by putting the words one after the other"; this way of thinking is so deep as it has served as a foundation of some actions for the automatic analysis of the language done in the 1950's of the last century. But the experience and knowledge on language show that not every automatic word combination may create a sentence.

This exercise of the questionnaire had eight sentences where eight foreign words hat to be put in the empty places. The words were: i adoptuar (adopted), live (live), eksperiencë (experience), present (present), fals (false), impression (impression), triumph (triumph), detaje (details). This aspect tended to investigate the recognition of the semantic meaning of the foreign word and the adoption of this word in Albanian language. In this way is assessed the suitability in the grammar system which plays an important role in usage of the words from the students even when these words are foreign and the level of recognition is low.

9 J. Lyons, Introduction in theoretical linguistics, Dituria Publishing House, Tirana, 2001. 
Grammar in itself represents a system of systems or planes, which are the planes of morpheme, syntagma and sentence. Since these grammar systems have their own structures, for them is preferred the term grammatical structure. This grammar structure is the ingredient that determines the individuality of a language. Despite the great influence that one language may have had on another language in lexicon and phonetic structure, it nevertheless remains an individual language, if it has kept its grammatical structure. The grammatical system constitutes the most stable side of the language." 10

The grammar also makes abstraction in sentence construction from the true content and takes what is general, the meaning and the formation scheme. The formal side of the sentence which is the lexical-grammatical and phoneticgrammatical side, is related to the combination of words according to the rules of the Albanian language, according to the types of syntax connections that function in the sentence, and according to the other necessary feature of each sentence, ending intonation, intonation characteristic for a certain type of sentence. ${ }^{11}$

The concept of sentence parts is related to tradition. Traditional grammar has distinguished the main parts of the sentence, which are the subject and the verb. Traditional theory about sentence parts is influenced by logic and regardless of any interpretation or study done, the sentence parts are an undeniable reality. ${ }^{12}$ This helps the user of foreign words starting from a theory, even when we have use of foreign words we have a difference in the use of cases, which are processed according to the Albanian ones. In the Albanian language we have the adaption of the name with the adjective, causing the name to take different forms depending on the relation it has with the adjective or other parts of speech. The syntax feature that makes a sentence a certain word combination is the one of being a predicative structure, and such a structure may be realized through the presence of a conjugated verb, but this is not necessary. ${ }^{13}$

\section{Results of the fourth measurement}

The results of this part show that participating students have very good knowledge of grammar system of Albanian language being this a very good indicator for the time period when our language is confronting the globalizing era where the foreign words are put in the presented paradigm even when their meaning or lexicon is not known. Often, they get the information on the meaning from the value that the word takes in the sentence. The students can identify the words and at least understand them in various sentences given in a certain text or speeches used from other speakers.

All what we notice is that in the lexicon plane, the words are put in the proper place. The students are right users of these words event though they might not know the meaning of these words. However, these words are often used in the media or everyday speaking. We also notice that the tendency to avoid using these words is getting more and more distant. What is being done is putting the words according to the suitability they have with each other, constructing a sentence which has a meaning.

According to the scholar Rami Memushaj "Language is a system of systems combined among them level by level where the lower level systems are part of a higher-level system, and this on itself is part of another system and so on. This means that the subsystems of the language may be imagined as planes with hierarchy planes. Each $f$ these planes has its own basic units which change from the basic units of other planes." 14

\footnotetext{
${ }^{10}$ Rami Memushaj, Introduction to linguistics, “Toena” Publishing, Tirana, 2014, pg. 187

${ }^{11}$ Rami Memushaj, Introduction to linguistics, "Toena” Publishing, Tirana, 2014, pg. 188

${ }^{12}$ Rami Memushaj, Introduction to linguistics, "Toena” Publishing, Tirana, 2014, pg. 246

${ }^{13}$ G. Graffi, Sintaksa- Structures of speech, Dituria Publishing, Tirana, 2003, pg. 125

${ }^{14}$ Rami Memushaj, Introduction to linguistics, "Toena” Publishing, Tirana, 2014, pg. 47
} 
ISSN 2661-2666 (Online) International Scientific Journal Monte (ISJM) DOI: 10.33807/monte.20211846

Volume 4, (No).1 (2021): April

Grammar is the main compound of the language, under its service are two other subsystems, phonetics and lexicon. The units of grammar system as elements of the first division of speech, have the plane of expression and of content, and at this point they are similar to lexicon units. ${ }^{15}$

${ }^{15}$ Rami Memushaj, Introduction to Linguistics, “Toena” Publishing, Tirana 2014, pg. 187 


\section{References}

Curriculum of Albanian language, MAS, Tirana, 2015

Rami Memushaj, Phonetics of the Standard Albanian, “Toena' Publishing, Tirana 2011.

B. Beci, Phonologic System of Today Literary Language and the phonetic form, Proper writing of Albanian Language, Tirana 1973.

Rami Memushaj, Standard Albanian, "Toena” Publishing, Tirana, 2008.

Rami Memushaj, Phonetics of the Standard Albanian, "Toena' Publishing, Tirana 2011.

Rami Memushaj, Introduction in Linguistics, “Toena” Publishing, Tirana, 2014.

J. Lyons, Introduction in Theoretical Linguistics, Dituria Publishing House, Tirana, 2001.

G. Graffi, Syntax- Structures of Speech, Dituria Publishing House, Tirana, 2003.

A.Giorgi, G. Longobardi, The Syntax of Noun Phrases, Cambridge University Press, 1991.

\section{Appendix}

\section{ANKETË}

MOSHA

SEKSI

KLASA

SHKOLLA

VENDLINDJA

\section{Në tekstin e mëposhtëm nënvizo fjalët e huaja.}

Qëllimi i këtij prezantimi është të konstatojmë në vlerat e këtij autori të njohur ndërkombëtarisht. Personalisht, ai ka qenë gjithmonë kundër dhe nuk ka insistuar në promovimin e veprave letrare të botuara. Por, është obligimi I të gjithë mediave, shkollave dhe individëve që e çmojnë letërsinë e mirë të flasin për teknikat e ndërtimit të veprës dhe mesazhet universale që mbart.

\section{Rretho përdorimin tënd në fjalët e dhëna.}

Proçes - proces

Eleminim - eliminim

defekt

Boljer - buljer - boiler
Pasaportë - pashaportë

Dixhital - digjital

Gjen - gen

Dakord- dakort
Garazh - garazhd Difekt -

Liçensë - licensë

\section{Zëvendëso fjalën e dhënë me ekuivalentin përkatës.}

Promovoj Insistoj

4. Plotëso vendet bosh me fjalët përkatëse (I adoptuar, live, eksperiencë, prezent, fals, impresion, triumf, detaje).

Ai nuk ishte në klasë kur u morën mungesat.

Të punuarit si shitëse ishte një e re për të.

Të shkuarit deri në majë të Korabit për të ishte një i madh.

E mori vesh shumë vonë nga prindërit e tij jobiologjikë se ishte

Në fund morëm vesh që u trembëm për hiçgjë, alarmi ishte

Gazetarja ishte ne lidhje

Galeria e pikturave i dha një

Fustani kishte kur ndodhi ngjarja tragjike. të jashtëzakonshëm kur i pa. 